\title{
Peace Operations and Organised Crime: Still Foggy?
}

Arthur Boutellis and Stephanie Tiélès

\section{INTRODUCTION}

Two and a half years after the initial deployment of the United Nations Multidimensional Integrated Stabilization Mission in Mali (MINUSMA), the UN Secretary-General noted in his report to the Security Council that "while positive steps were taken towards the implementation of the peace agreement by the signatory parties, there was an increase in the number and geographical spread of activities by extremist and terrorist groups and organized crime networks" and that "MINUSMA convoys remained the primary target of extremist and terrorist groups and transnational drug traffickers on the main supply routes" (UN 2015a). The Council, when it first authorised MINUSMA in June 2013, had foreseen the "serious threats posed by transnational organized crime in the Sahel region, and its increasing links, in some cases, with terrorism" and

\footnotetext{
A. Boutellis $(\bowtie)$

International Peace Institute (IPI), New York, NY, USA

S. Tiélès

Central Directorate of Judicial Police (International Relations Division), Nanterre France

(C) The Author(s) 2019

C. de Coning and M. Peter (eds.), United Nations

Peace Operations in a Changing Global Order, https://doi.org/10.1007/978-3-319-99106-1_9
} 
underscored "the urgent need to address these issues." Yet, it did not give any specific tasks or guidance to the UN stabilisation mission in terms of organised crime and has instead encouraged "Member States of the Sahel region to improve coordination to combat recurrent threats in the Sahel, including terrorism, together with transnational organized crime and other illicit activities such as drug trafficking" (UN 2015b) or welcomed initiatives and "efforts of the Group of Five for the Sahel (G5) ... to strengthen regional security cooperation .... and to establish a new counterterrorist centre" (UN 2016).

This reflects the increasing disconnect between the growing recognition by the UN system and Member States over the past decade that organised crime (OC) is a problem that cannot be ignored where the UN has peace operations on the ground. It also reflects the fact that the UN system and Member States are still uncertain about how to approach a phenomenon that lacks a precise definition ${ }^{1}$ and, more importantly, refers to various criminal activities or threats understood differently based on contexts and perceptions. Although organised crime and trafficking are now considered a threat to security and stability in post-conflict countries in their own right, they also continue to be most often considered in their relation to terrorism and violent extremism (UN 2015 c), which is not always helpful for developing realistic peace operations approaches to OC.

In recent years, the Sahel region witnessed the proliferation of international forces and regional ones ${ }^{2}$ resulting in a securitisation of approaches when a number of experts called for more nuanced human security-based approaches to addressing the organised crime-terrorism threat: "States and regional organizations [need] to pause and reexamine their counterterrorism and counterinsurgency measures, which by militarizing the region are exacerbating the problems and fail to address the fundamental issues that affect the region" (Kfir 2016). There is also a

\footnotetext{
${ }^{1}$ The 2000 UN Convention against Transnational Organized Crime defines OC as " $a$ structured group of three or more persons, existing for a period of time and acting in concert with the aim of committing one of more serious crimes or offenses established in accordance with this Convention, in order to obtain, directly or indirectly, a financial or other material benefit."

${ }^{2}$ International forces include the French counterterrorism force Barkhane and the UN mission MINUSMA and regional ones include the joint force of the Group of Five for the Sahel (G5 Sahel) which was just established and includes an explicit mandate to combat transational crime in addition to terrorism.
} 
growing body of literature suggesting that OC may not always be the enemy of peace operations, and can indeed benefit from the minimal level of stability and both licit and illicit business opportunities provided by the presence of peacekeepers - themselves not immune-and/or sanctions regimes and embargoes.

Nowadays, almost three-quarter of UN peace operations-ranging from small political missions without armed components in Guinea Bissau, Afghanistan, Libya, Somalia, and most recently Colombia (including unarmed military observers) to large multidimensional peacekeeping operations like the ones in Haiti, Kosovo, the Democratic republic of Congo (DRC), the Central African Republic and Mali-operate in environments that are considered significantly affected by organised crime (OC). It was, however, only in 2010 that the UN Security Council invited the Secretary-General to consider the threats posed by organised crime in mission planning and reporting (UN 2010). Yet, of current UN peace operations, less than half have explicit mandates related to organised crime, fewer have mandates to tackle criminal groups spoilers directly, and those that do are still not well-prepared to face this threat in terms of policy, doctrine, strategic and operational guidance, and capacities (Kemp et al. 2013).

This chapter first looks back at how and why organised crime has increasingly become recognised as a threat to international peace and security and as a UN peace operations problem. It then reviews the dominant law enforcement and capacity-building approaches adopted so far for UN peace operations to deal with organised crime and their limits. It finally explores the way forward for how the UN could deal more realistically and effectively with transnational organised crime in the future. While taking a historical approach, the chapter focuses particularly on the Mali/Sahel example as the latest laboratory for (re-)defining the relationship between UN peace operations and organised crime.

\section{The Growing Recognition of Organised Crime as a STrategic Threat}

A number of studies and United Nations reports have over the past two decades demonstrated how armed groups-including terrorist groupsresort to illicit trafficking to finance their activities, and how organised crime can be an important driver of conflict and instability in some post-conflict and fragile states, particularly when it penetrates and/ 
or co-opts States institutions at the local and national levels. The 2004 Report of the High-level Panel on Threats, Challenges and Change recognised transnational organised crime as one of the six clusters of threats with which the world must be concerned now and in the decades ahead, because it facilitates many of the most serious threats to international peace and security. The Panel's recommendation at the time, however, solely focused on the need for better international regulatory frameworks and building State capacity in the area of the rule of law. The 2011 World Development Report also emphasised that the penetration by organised crime of the already vulnerable socio-political, judicial, and security structures in developing countries can be a serious obstacle to peacebuilding and economic development, and made the case for longerterm approaches to building effective state institutions.

The United Nations initially approached criminal activity and trafficking issues in relation to conflict situations already on the Security Council's agenda, particularly where UN peace operations were deployed in the Balkans, Central America, the DRC, Haiti, Somali, and West Africa. And while the link between drug trafficking and terrorism contributed to moving the issue up the Council's agenda in the 2000s, particularly in the context of Afghanistan, the Council later started considering whether drug trafficking and organised crime could constitute in themselves a threat to international peace and security. This was illustrated by a series of thematic debates, presidential statements and resolutions since 2009, and in December 2015, the Council added human trafficking to the list of criminal activities whose impact on conflict it has considered. The Council also "moved furthest, fastest, where the criminal activity in question threatened permanent members' interests, the country was already on the Council's agenda, and no state with influence in the Council had a particular reason to limit such experimentation" (Cockayne 2015).

These developments culminated with the 24 February 2010 Security Council Presidential Statement (PRST) noting the "serious threats" posed by drug trafficking and transnational organised crime and the financing of terrorism to international security, and noted that these "may threaten the security of countries on its agenda" and expressed its intention to "consider such threats, as appropriate." In the same statement, the Council also invited the Secretary-General "to consider these threats as a factor in conflict prevention strategies, conflict analysis, integrated missions' assessment and planning and to consider including in 
his reports, as appropriate, analysis on the role played by these threats in situations on its agenda" (UN 2010).

This was the basis for the establishment a year later of an internal UN System Task Force on Transnational Organized Crime and Drug Trafficking, co-led by the UN Office on Drugs and Crime (UNODC) and the UN's Department of Political Affairs (DPA) to develop an effective and comprehensive approach to the challenge of transnational organised crime (TOC) and drug trafficking and coordinate UN actions in these areas, primarily through assistance to states. While this task force has had a slow start and produced little guidance, it may have contributed to raising the profile of organised crime (traditionally a UNODC 'turf') more broadly within the organisation, as illustrated by the recent development of a UN "Transnational Organized Crime and Security Sector Reform" guidance note by the UN Inter-Agency Security Sector Reform Task Force. In 2013 the Secretary-General's Policy Committee requested the Task Force (in Decision 2013/3) to "share experiences across regions on what it means in practice to adopt 'comprehensive UN approaches' to drugs and crime, including lessons learned/good practices notes on thematic issues such as crime-sensitive ... peacebuilding, and conflict prevention policies," and to "produce a guidance note on how to include issues related to drug trafficking and organized crime in conflict analysis and integrated assessment processes" but at the time of the writing of this chapter, the guidance note had still not been produced.

\section{Persistent Hesitancy on How to Approach Organised Crime in UN Peace Operations}

Organised crime is present in almost three quarter of the countries where the Security Council has authorised the deployment of UN peace operations-ranging from small political missions without uniformed components to large multidimensional peacekeeping operations. OC does, moreover, present a threat, sometimes direct (in terms of safety and security of UN personnel as in the case of Mali); but most of the time indirect, in that it hampers the implementation of the mandate and bolsters the spoiling capacity of certain groups in places like Guinea Bissau, Afghanistan, Libya, Somalia, Haiti, Kosovo, the DRC, etc. But despite the above-mentioned 2010 PRST, the Security Council has so far been hesitant to give specific mandates to its peace operations, with less than 
half of the resolutions mandating these operations to make reference to organised crime and fewer mandating UN operations to tackle criminal groups spoilers directly (Kemp et al. 2013).

While a number of reasons explain the Council's hesitation, it has led to a "chicken and egg" situation. The lack of a clear mandate (most references to organised crime are in the preamble of Council resolutions rather than in operative paragraphs) limits the ability of UN operations to focus and devote resources to analysing and possibly starting to address organised crime beyond limited capacity building efforts (in security sector, rule of law reform, and border management). And, in turn, it limits their ability to shed light on the issue and its far-reaching implications when reporting to the Council. That said, the lack of specific reference to organised crime in the mandate did not stop past leaderships from at certain times being proactive in the UN missions in Kosovo (UNMIK) and Timor-Leste (UNTAET) - notably under rare so-called "executive" mandates which have not been reiterated sinceor Haiti (MINUSTAH, see below). Conversely, despite having a specific crime fighting mandate, the mission in Guinea Bissau (UNIOGBIS) has had little success in implementing it in part due to the lack of political will from the successive host governments and the limited leverage and capacities of the small UN political mission. The latest Security Council resolution 2343 (2017) on Guinea Bissau nonetheless reemphasised the issue of organised crime and the need to support the West Africa Coastal Initiative (WACI) - a regional programme co-led by UNODC, DPA/UN Office for West Africa and the Sahel (UNOWAS), the UN Department of Peacekeeping Operations (DPKO) and INTERPOL.

Generally, UN peace operations have been largely "flying blind" when it comes to transnational organised crime, particularly the UN Special Political Missions (SPMs) with the least resources and presence on the ground. A particular limitation has been that (host country) consent-based peace operations have not been mandated to "address the nexus between organized crime and national political or power dynamics, which increasingly constitute the driving force behind instability in various regions" (Cockayne and Kavanagh 2011). But while organised crime is obviously a challenge that goes far beyond the mandate and lifetime of a peace operation, the failure to look into the problem at an early stage arguably risks making it even more difficult to deal with later when it has further infiltrated the very government and state institutions that the UN seeks to strengthen. As Mats Berdal notes, many post conflict 
settings are characterised by the "ability of organized crime to take root and flourish in periods of transition from war to peace, to develop symbiotic relationships with local political elites and strengthen ties to transnational criminal networks" (Berdal 2009, p. 62). A recent review of the literature commissioned by the UK government's Stabilisation Unit indeed concluded to an emerging consensus among scholars that in conflict and post-conflict settings political and criminal actors are not necessarily adversarial, but may in fact collaborate and even merge (Scheye 2015, pp. 3-7). The traditional peace operations distinction between political and criminal actors would therefore be largely misleading.

Some of the more innovative UN approaches to organised crime may have come from the DPA regional offices, particularly the UN Office for West Africa (UNOWA)-recently renamed UN Office for West Africa and the Sahel (UNOWAS)—which has helped raise awareness on the threat represented by organised crime and drug trafficking in West Africa, including through its June 2011 reporting to the Security Council that the "corrupting effects [which] have further weakened already fragile State institutions and may finance armed or terrorist groups operating across West Africa and the Sahel." The West Africa Coastal Initiative (WACI) has also been praised for its regional approach combining a political level (with a High-Level Policy Committee chaired by the UNOWA head) - to encourage the political will of regional heads of states - and an operational level consisting of building Transnational Crime Units (TCUs) in Sierra Leone, Liberia, Côte d'Ivoire, GuineaBissau, and Guinea.

Initially launched in 2009 to support the implementation of the Economic Community of West African States' Action Plan to Address the Growing Problem of Illicit Drug Trafficking, Organized Crime and Drug Abuse in West Africa, the WACI was extended until 2017 with a possible enlargement to Benin and Togo. WACI contributed to enhancing both operational law enforcement capacities and inter-agency cooperation at the national level and international coordination by strengthening intelligence-based investigations. Since 2014, the first fully operational TCUs in Liberia, Sierra Leone and Guinea Bissau carried out joint operations and have been using INTERPOL tools and services. Notably, these TCUs continued operating during the 2014/2015 Ebola outbreak with UNODC's operational and logistical support. The strength of the model, which is its national ownership and empowerment, has, however, also become a challenge where host states are less supportive and even 
resistant of international involvement in some cases. Another major concern has been the vetting of TCUs personnel and the risk that they may not be immune from corruption by powerful criminal networks. The sustainability of such an onerous project is also at risk of a funding gap, which may be the result of donors refocusing their efforts on emerging threats on terrorism, violent extremism, and illegal migrations from the region.

Despite this growing recognition that criminal groups can act as a spoiler to peace processes and represent a strategic threat to the successful implementation of a mission's mandate and of the fact that peace operations could play a role in managing or disrupting organised crime, the question of whether peace operations are the right instrument to deal with organised crime at the operational level, and if so how they should deal with the problem, remains largely unanswered since the first major publication on peace operations and organised crime (Cockayne and Lupel 2011). The lack of UN success stories and so-called "best practices" in this specific area has also surely played a part. While some lessons could have been identified from earlier crime-fighting European missions such as EU Police Mission in Bosnia Herzegovina (2003) or the EU Rule of Law Mission in Kosovo, these contexts are very different from the ones UN missions now face on the African continent.

Amid this confusion and competing priorities, the UN has so far not invested in developing system-wide policy and strategic guidance that factors in organised crime. The most recent UN peacekeeping strategic documents, the 2008 Capstone Doctrine-which introduced the concept "robust peacekeeping" as a recognition that force may be used at the tactical level against spoilers in some cases-and the 2009 New Horizon-announcing that the UN is "working to identify essential early tasks as the first step to a coherent post-conflict stabilization strategy" - only make few passing references to organised crime, and have yet to result in a UN stabilisation doctrine which would factor in the destabilisation impact of such threats. Similarly, while the DPA 2016-2019 Strategic Plan mentioned TOC upfront alongside "violent extremism" as a major issue, no concrete policy responses are mentioned beyond the need for strengthening partnerships within the organisation to address such transnational and cross-cutting challenges.

The best illustration of such disconnect between the diagnosis and the prescription is the United Nations Multidimensional Integrated Stabilization Mission in Mali (MINUSMA). The issue of peace 
operations and organised crime has arguably never before been as relevant as in the Mali/Sahel context, with the 2012 Mali crisis illustrating the potentially destabilising impact of criminal networks in the region, not only because illegal trafficking became the dominant economy of Northern Mali overtime and contributed to financing activities of armed groups, but also because the increasing profits from drug trafficking and kidnapping-for-ransom activities led to the corroding of State institutions eventually leading to the collapse of the Malian State (Lacher 2012). Yet, despite broad recognition among member states and UN Secretariat that organised crime is a problem in Mali, the mandate given to MINUSMA was not different from that of other UN missions. Three years into the mission, Resolution 2295 of June 2016 (UN 2016), although it authorised a more "proactive and robust posture" in an attempt to prevent asymmetric attacks, did not give any specific instructions to MINUSMA as to what to do about trafficking in weapons, drugs and humans, which at least in some cases are linked to terrorist networks. With most of the mission's military assets dedicated to self-protection, and no obvious solution to trafficking in areas beyond the government's control, organised crime easily falls down the agenda.

\section{The Limitations of Consent-Based Peace Operations}

Beyond the lack of mandate and strategic guidance, one must acknowledge the many risks and inherent limitations for peace operations to address the issue of organised crime effectively. First of all, this is because organised crime takes very different shapes and forms from one place to another and evolve over time to adapt to changing realities. UN peace operations, on the other hand, are deployed for a finite period of time which limits its ability to adapt and adopt effective longer-term strategies (that in many cases would imply the transformation of economic and power structures) against organised crime. This is rendered even more complex by the fact that the leadership of UN operations are faced with many competing tasks and priorities-for instance supporting the political process and the restoration of state authority-with urgent issues often prioritized over the important OC issues.

Haiti is a good example. Here, the UN Stabilization mission (MINUSTAH) carried out robust intelligence-led operations against gangs in 2006 and 2007 in support of the government, which have largely been successful in taming the challenge to stability posed by 
political violence and armed gangs. The UN mission later refocused its efforts away from enforcement towards the development of the capacities of the Haitian National Police but without addressing the underlying causes of organised crime and trafficking. As a result, while the UN may have been a strong deterrent for violence since, it has not been a deterrent for illicit activities and the UN risks now withdrawing MINUSTAH and leaving a country where organised crime has become further embedded in state institutions, including security forces that may be profiting from crime rather than fighting it. ${ }^{3}$

The fact that most UN peace operations (with the notable exception of regional offices) are geographically limited to one country is also a serious limitation to analysing organised crime and trafficking that profit from operating across borders and regions. A further concern has been the limited resources, tools, and expertise available to date to peacekeepers in terms of criminal intelligence and political economy analysis but also the lack of a legal framework for developing such "supranational" capacities. In many cases, the host government may not consent to the UN mission investigating criminal networks, which in many cases would lead to uncovering links - support, penetration, or co-optation-to both armed groups and the government itself, which would naturally strain relations with the host State. This may partly explain why until now the Security Council has preferred mandating independent Panels/Groups of Experts monitoring sanctions regime to look into issue of illegal arms and minerals trafficking. The recent resolution 2374 creating a sanctions regime in Mali targeting actors derailing the peace process actually lists organized crime and traffics as possible sources of financing for spoilers. ${ }^{4}$

Another recurrent challenge raised by both troop and police contributing countries (TCCs/PCCs) is the safety and security of the personnel in UN peace operations. Indeed, in most cases organised crime does not represent a direct threat to peacekeepers until peacekeepers either get involved, or attempt to expose, contain, or disrupt its illegal activities. While in some cases UN missions may have the ability to deal

\footnotetext{
${ }^{3}$ See Haiti case study in Kemp et al. (2013, p. 32).

4 "supporting or financing individuals and entities ... including through the proceeds from organized crime, including the production and trafficking of narcotic drugs and their precursors originating in or transiting through Mali, the trafficking in persons and the smuggling of migrants, the smuggling and trafficking of arms as well as the trafficking in cultural property" (UN 2017).
} 
militarily with some spoilers (the local gangs in Haiti or armed groups in the eastern DRC), in other cases, "going on the offensive" against powerful organised crime and trafficking networks with links to armed groups would likely result in direct retaliations against the UN mission and personnel on the ground. Similarly, UN police starting to investigate organised crime-even in support of their national counterparts-could present potentially serious security concerns for UN personnel. Some may even themselves become involved or complicit of powerful OC and trafficking networks when UN operations still have no security clearance and/or counter-intelligence systems in place.

\section{A Constrained Police Capacity-Building Approach}

In the midst of this quasi absence of UN strategic guidance for peace operations on organised crime and in light of the challenges above, the UN Police Division has taken the lead in promoting a law enforcement capacity-building approach. Its February 2014 DPKO/DFS Policy on United Nations Police in Peacekeeping Operations and Special Political Missions states that "addressing organized crime and strengthening the rule of law have taken on greater importance in most peacekeeping operations and special political missions and is an important entry point for engaging with national authorities to take action." Activities suggested include to "support the planning and implementation of host State and regional operational and analytical capacity-building activities" in partnership with UNODC, the United Nations Development Programme (UNDP), INTERPOL and other relevant actors, as well as "anticorruption initiatives; assessments and engagement with the public [...] and strengthen the capacity of the criminal justice system" (UN Police 2014). The 2016 External Review of the UN Police Division confirmed this tendency by suggesting the better factoring of OC at headquarters in order to better support missions in the field in an exhaustive manner.

The Security Council endorsed this approach in November 2014 when "highlighting the important role that United Nations Police Components can play in building the capacity of host-State policing and other law enforcement institutions, as mandated, to address organized crime, particularly through support in the areas of border, immigration and maritime security and crime prevention, response and investigation." It however also encouraged information sharing between Special Representatives of the Secretary-General, DPKO including the Police 
Division, DPA, Counter-Terrorism Committee Executive Directorate, UNODC, Counter-Terrorism Implementation Task Force and UNDP "within existing mandates and resources, when considering means to address, in a comprehensive and integrated manner, transnational organized crime, terrorism and violent extremism which can be conducive to terrorism" (UN 2014a), thereby emphasising the need for a UN system-wide approach.

The following month, the Council issued a resolution calling on "relevant entities of the UN and other relevant international and regional organizations to support the development and strengthening of the capacities of national and regional institutions to address terrorism benefitting from transnational organized crime, in particular law enforcement and counter-terrorism agencies" and reiterated that peace operations "may, if mandated by the Council, assist in capacity-building for host governments, as requested, to implement commitments under existing global and regional instruments and to address the illicit trafficking of weapons" (UN 2014b, paras. 16 and 18). While that same resolution reaffirmed the lead role of the UN in coordinating international efforts in combating "international peace and security caused by terrorists profiting from involvement in transnational organized crime," this continues to be a challenge in practice with many international actorsbilateral, regional, and international—often driving competing agendas through capacity building projects in support of national authorities.

One of the challenges will indeed be for UN peace operations to reconcile a fairly narrow law enforcement capacity-building police approach with the need for a UN system-wide approach to preventing and addressing organised crime-and its links to terrorism and violent extremism-that remains to be defined. In Mali for instance, the UN Police component played a leading role and developed unprecedented initiatives. It created a twenty-five people Serious and Organized Crime unit dedicated to supporting Malian authorities with counterterrorism and TOC training and equipping, including the newly developed Malian Judicial Division specialised in the fight against terrorism and transnational crime. The UN Police has been considering and appealing to PCCs for some years already for the deployment of readily formed specialised team. With the increasing consideration given recently to Serious and Organized Crime, the UN aims at fostering the recruitment of specialised teams of law enforcement practitioners in peace operations. The specific nature of such police work requires specific expertise and 
specialisation. The lack of international standards on how to tackle organised crime groups might, however, challenge the pressing need of supporting host state security forces when threatened by complex criminal organisations. In Mali, by dedicating specialised crime advisers covering a wide range of police technics against illegal activities, the United Nations Police increased its ability to provide an in-depth expertise in the complex fields of forensics, criminal intelligence and large scale investigation. The UN Police also established a MINUSMA Task Force on Counter-Terrorism and Organized Crime in Mali in mid-2014-which includes representatives from UNODC and a number of MINUSMA Sections, as well as UNDP. The Action Plan it designed, however, disregarded the linkage between security and development by focusing only on supporting the Malian law enforcement agencies, judiciary, and corrections sectors, and does not in itself constitute a UN system-wide strategy to organised crime in Mali.

A study by the international non-government organisation Transparency International (TI) submitted that "International involvement in defense operations that doesn't take corruption into account can exacerbate the problem, and security assistance can make a country less secure if it isn't accountable [...] In Mali, security assistance was focused on tactical training and equipping troops, but didn't address structural and institutional weaknesses like corruption" (TI 2015). Indeed, in addition to the need for the UN to adopt a more integrated approach to justice and security sector reform, any strategy to prevent and combat transnational organised crime should consider the fight against state corruption as a foremost concern to be first addressed at the macro level, before any action is taken at the operational level to strengthen the capacity of local law enforcement agencies. Short of this, the UN risks strengthening security and political institutions that are part of the problem rather than the solution because they are already corrupted by criminal groups. Meanwhile, the UN could do more at the micro/local level to mitigate factors bolstering OC and trafficking and to build local communities' resilience particularly where and when the state is absent.

Academic research advises refocusing security sector reform on the needs of individuals and communities in order to avoid building the capacity of government structures which can inadvertently supports officials connected to crime (Jesperson 2016). Furthermore, such an approach would reinforce the confidence of the local population in their national institutions and deter them from relying on alternatives provided 
by criminal or armed groups. In cases where the host country authorities may be part of the problem or lack political will, some research has also suggested to better acknowledge the penetration of organised crime by encouraging development actors to make smarter use of a range of tools to determine when to engage and where to prioritise efforts. A detailed assessment of interests and stakeholders would enable development actors to determine political obstacles to engagement (Kavanagh et al. 2013). Nevertheless, the high turnover in mission leadership and lack of longer term strategies (partly due to mandates that are renewed every year) also affects the ability of the mission to make a difference.

The fairly narrow police capacity building and law enforcement approach to organised crime adopted so far, however, seems to be more of a default position resulting from both the complexity of the issue at stake and the lack of clarity and strategic guidance from Member States and the UN Secretariat on what the role and approach of peace operations could and should be beyond policing. The deployment of a UN stabilisation mission in Mali with unprecedented analytical and uniformed capacities has brought the issue of organised crime back on the radar of UN peace operations and made MINUSMA a new laboratory. Already in an October 2013 report, the UN Secretary-General mentioned "the fight against corruption and organized crime" as an equally important governance challenge to the effective functioning of the Malian state, alongside security sector reforms, national dialogue, and reconciliation and justice (UN 2013, para. 82). So if the UN were serious about organised crime, what could/would it do?

\section{The Way Forward: A More Strategic and Holistic Approach to Organised Crime in Peace Operations?}

First and foremost, the UN needs to develop better information collection and analysis capacities when it comes to organised crime. In Mali, the NATO-standard All Sources Information Fusion Unit (ASIFU) brought unprecedented analytical capabilities to the UN mission but information collection itself was not well integrated into the mission's existing information and intelligence infrastructure. ${ }^{5}$ Similarly, the military

\footnotetext{
${ }^{5}$ In the course of 2017, ASIFU was merged with the Military Intelligence Unit (U2) in an attempt to better integrate the mission's various information collection and analysis capacities.
} 
intelligence subscribes to a different methodology and purpose that can be incompatible with the kind of criminal intelligence and political economy analysis required for analysing criminal networks and their impact and better understand the political, criminal, and terrorist nature of diverse armed groups. A more effective approach may be to develop mission-wide OC analytical capacities so that various staff within the mission (political affairs/mediation, civil affairs, Joint Mission Analysis Center (JMAC), police, justice, Disarmament, Demobilization, and Reintegration (DDR), etc.) are able to detect, collect and analyse relevant information on an ongoing basis, in liaison with regional UN officessuch as UNOWAS and UNODC in the case of MINUSMA- and the Panel of Experts when they exist, to factor in cross-border regional issues. Such information should then be centralised-Ideally within the JMAC, which combines civilian, police and military personnelto produce forward-looking strategic analysis identifying opportunities and suggesting both strategic and operational responses to prevent, avert, or mitigate threats to mandate implementation for mission leadership. In April 2017, DPKO released a Peacekeeping Intelligence policy meant to address some of these systemic challenges and is envisaging creating Criminal Intelligence Unit (CIU) comprised of specialised intelligence police officers within missions, but member states remain divided on even the use of the term intelligence.

A number of assessment tools already exists—such as the one used by UNODC-DPA for regional TOC Threat Assessment (UNODC 2010) and Spotting the Spoilers: A Guide to Analyzing Organized Crime in Fragile States (Shaw and Kemp 2012) — that can be used to train and sensitise relevant mission staff. Early literature on peace operations and OC suggested that peacekeeping missions should adopt a "spoiler management" approach to avoid excluding certain actors or reverting to a law enforcement approach by labelling them as criminal. Instead, one ought to focus on the mission's attention on "managing" spoiling behaviour and activities rather than the impossible task of fighting OC in general (Cockayne and Lupel 2011). The problem of course is that, often, OC may not produce violence in the short term-and may even contribute to stability. But in the medium to longer run, however, organised crime can effectively undermine the very objective of stability and the building of functioning state institutions.

In the first comprehensive review of UN peace operations since the 2000 "Brahimi report," the 2015 High Level Independent Panel on 
Peace Operations (HIPPO) may have overlooked the issue of the impact of criminal agendas on the work of peace operations, but nonetheless made three recommendations that can be helpful in adopting crime-sensitive approaches in the future: First, it recommends to strengthen the underlying analysis towards designing better and more effective political strategies, mandate sequencing to allow for better informed strategic planning, and more "people-centric" operations. The UN SecretaryGeneral subsequently established a small centralised analysis and planning capacity in his office, which could play an important role on mainstreaming organised crime into analysis and planning before preparing strategic considerations and options for possible UN responses (UN 2015d). For example, the presence of violent criminal actors may suggest the need for a uniformed component with more qualified police over military. Second, the HIPPO recommends a sequencing approach that could, for instance, allow a better "tailoring" of a mission as the UN develops a better understanding of the impact of organised crime but also of the political will and capacities of the host governmentwhich in some cases may be part of the problem-with whom the UN could establish "Compacts." 6 Third, it recommends a "people-centric" approaches to peace operations, in that it could help adopt measures to address and prevent OC that risk alienating communities-including by depriving them of economic opportunities and hurting their livelihoodand instead help peace operations strengthen resiliency (UN 2015e).

Amid lots of attention on the OC issue in Mali and the Sahel, the HIPPO report also recognised that transnational organised crime "is a mission-wide concern and a strategic risk to sustaining peace" but its only recommendations was that the UN acquire police expertise in this area "when requested and in partnership with others to support national police capacity" (UN 2015e, para. 160).

Beyond technical fixes, research points to a more fundamental shift in addressing organised crime in fragile state by moving away from the traditional dominance of security and law enforcement approaches—so far

\footnotetext{
${ }^{6}$ The idea of "Compacts" was put forward by the 2015 HIPPO Report suggesting that UN "mission leadership should be empowered and supported to assess- through broad consultations with national actors, the UN Country Team and other international actors as required-the context and the most appropriate package of measures to help sustain peace, to be reviewed together with mandate renewal. This package should form the basis of a compact between the UN and the host government" (UN 2015e, para. 146).
} 
used by the UN-to a greater role for development actors and partnerships. Instead of solely reforming the security sector, capacity building programmes should involve more civil society to monitor the practices of the security sector, and focus more on citizen security rather than state security (Jesperson 2016). The development response to drug trafficking in West Africa studied by the US Agency for International Development (Dininio 2015), has tabled suggestions in that sense for how development actors can better assess when and where to provide support in countries where trafficking is prevalent. USAID suggests that development programmes should include adequate flexibility to be able to adapt to emerging threats by closing activities, shifting locations, or introducing complementary programming activities especially in areas where government counterparts are identified as complicit. This flexibility would require the UN missions to undertake a continuous and meaningful analysis of the impact of organised crime and less bureaucratic rules to have a nimble ability to support accordingly.

Some existing peace operations activities could, however, benefit from adapting some of the "traditional" UN peace operations tools. For instance, James Cockayne (2013) has suggested the strengthening of mediation to deal with criminal agendas and armed groups involved in illicit activities, which if ignored could spoil peace processes. In Mali for instance, the parallel "business deals" between politico-military leaders and businessmen at the head of armed groups seen in late 2015, taking place outside the formal international mediation process, carry the risk of the reestablishment of a militarised political-economic system that was the source of much of the violence in the first place in northern Mali (International Crisis Group 2015). But conversely, if such deals come in support of a national peace process-as seems to have been the case in November 2017-they could also contribute to stability. DDR and Community Violence Reduction (CVR) programmes could also be used in innovative ways to provide at least short-term alternatives to illicit economies. Indeed, while UN peace operations cannot transform the political economy of a country, incentive-based, more people-centric, and non-repressive approaches are essential complements to the law enforcement capacity building approaches described above.

Recent research by the United Nations University (UNU) suggests peace operations should adopt a more holistic "Crime-Proofing Peace-Making" approach. It gives practical but ambitious pointers on what the UN could do to protect electoral processes from penetration by criminal financiers, how 
it could tailor the use of sanctions to address crime-politics connections and avoid unintended consequences, make use of strategic communications to disrupt and degrade criminal legitimacy, and use gender smart approaches (Bosetti et al. 2016). Naturally, the issue of OC goes beyond the mandate, capacities, and time span of peace operations, and require better Member State cooperation as well as longer-term and system-wide approaches both within the UN (including the UN development system) and beyond (INTERPOL, International Financial Institutions, etc.).

Some have, however, also highlighted the limitations of current Statebased bilateral and multilateral law enforcement approaches and of the tools to fight transnational and multidimensional networks. Notably, the Global Initiative Against Transnational Organized Crime initiated in 2011, which brings together senior law enforcement officials, representatives of multilateral organisations, development practitioners, and policymakers in a "network to counter networks," has been calling for a more strategic and proactive global approach to counter transnational crime and trafficking (The Global Initiative 2011). UN operations, in the relatively short time they are deployed, could benefit from closer collaboration with such networks of experts. Whenever faced with a new issue, the tendency of the UN has too often been to expand the bureaucracy by creating new specialised units and posts when sometimes it may be best to partner with others or bring temporary thematic (political economy, criminal intelligence etc.) and region/country-specific (with necessary language skills) expertise on board for shorter periods of time.

\section{CONCLUSION}

In conclusion, despite the recognition by the UN system and Member States that organised crime is a threat to peace and stability, particularly when in conjunction with terrorism and violent extremism, there is still much uncertainty about how to address it, and even more uncertainty about what UN peace operations could and should do about it. The field of peace operations and organised crime remains relatively new, with literature on the issue dating less than a decade. Moreover, the UN started officially considering the threats posed by organised crime in mission planning and reporting on it only in 2010. And the issue has become front and centre, with almost three quarters of UN peace operations now operating in environments significantly affected by organised crime, particularly in the West Africa and Sahel contexts. 
Much of the debate until now, however, has remained at the conceptual level around the fact that OC could represent a strategic threat to the successful implementation of a mission's mandate, and little has been experimented at the operational level on how a peace operation could practically deal with the problem. Yet, the story of UN peace operations is one of trial and error at the field level leading to lessons that eventually make it into policy through a bottom-up approach rather than the reverse. In that sense, recent experiments with the regional WACI project, a specialised Serious and Organized Crime police unit in MINUSMA, and the increasing acceptation of the need for UN missions to collect and analyse 'intelligence' (including criminal intelligence) are useful developments that will generate further lessons. Much can also be achieved through adapting some of the existing UN tools (such as mediation and DDR but also assessments, elections, strategic communication etc.) and generate greater coherence between missions, UN Country Teams, Regional Offices, UNDP, and UNODC, to ensure that the mission's efforts are part of a longerterm strategy.

Such developments at the operational level however need to be accompanied by a broader strategic thinking on when and where to engage, based on a thorough analysis of opportunities and risks that should factor in the political economy of the country, corruption of state institutions, and the political will of the host government (or lack thereof) so that the mission's efforts do not become part of the problem rather than of the solution. UN peace operations also need to become more people-centric and focus more on prevention-rather that the elusive goal of countering $\mathrm{OC}$ - by mitigating factors bolstering trafficking and facilitating the strengthening of communities' resiliency through partnerships with UN development actors and international and local non-governmental organisations. This chapter does not suggest that every mission deployed in an environment significantly affected by organised crime should make it one of the mission's top priority, and it certainly does not suggest that UN peace operations can tackle the issue on their own. However, whether and what to do about it, and whom to partner with in this endeavour, should be a deliberate decision based on an informed analysis. 


\section{REFERENCES}

Berdal, Mats. 2009. Building Peace After War. London: Routledge.

Bosetti, Louise, James Cockayne, and John de Boer. 2016. Crime-Proofing Conflict Prevention, Management, and Peacebuilding: A Review of Emerging Good Practice. Occasional Paper 6, United Nations University Centre for Policy Research, Tokyo.

Cockayne, James, and Adam Lupel. 2011. Peace Operations and Organized Crime: Enemies or Allies? London: Routledge.

Cockayne, James, and Camino Kavanagh. 2011. Flying Blind? Political Mission Responses to Transnational Threats. Review of Political Missions 2010. New York: Center for International Cooperation.

Cockayne, James. 2013. Strengthening Mediation to Deal with Criminal Agendas. Geneva: Center for Humanitarian Dialogue.

Cockayne, James. 2015. Confronting Organized Crime and Piracy. In The UN Security Council in the 21st Century, ed. Sebastian von Einsiedel, David M. Malone, and Brunos S. Ugarte. New York: Lynne Rienner.

Dininio, Phyllis. 2015. Organized Crime, Violent Conflict and Fragile Situations Assessing Relationships Through a Review of USAID Programs. Arlington: Management Systems International.

International Crisis Group. 2015. Mali: Peace from Below? Africa no. 115, December 14, International Crisis Group, Dakar and Brussels.

Jesperson, Sasha. 2016. Rethinking the Security-Development Nexus: Organised Crime in Post-conflict States. Routledge Studies in Conflict, Security and Development.

Kavanagh, Camino, Kwesi Aning, Vanda Felbab-Brown, James Cockayne, Enrique Desmond Arias, Charles Goredema, Sampson B. Kwarkye, John Pokoo, and Summer Walker. 2013. Getting Smart and Scaling Up: Responding to the Impact of Organized Crime on Governance in Developing Countries. New York: Center on International Cooperation.

Kemp, Walter, Mark Shaw, and Arthur Boutellis. 2013. The Elephant in the Room: How Can Peace Operations Deal with Organized Crime? New York: International Peace Institute.

Kfir, Isaac. 2016. Organised Criminal-Terrorist Groups in the Sabel: Why a Counterterrorism/Counterinsurgency-Only Approach Ignores the Roots of the Problem. Institute for National Security and Counter-terrorism.

Lacher, Wolfram. 2012. Organized Crime and Conflict in the Sabel-Sahara Region. Washington, DC: Carnegie Endowment for International Peace.

Scheye, Eric. 2015. Organised Crime in Stabilisation Contexts. London: UK Stabilisation Unit.

Shaw, Mark, and Walter Kemp. 2012. Spotting the Spoilers: A Guide to Analyzing Organized Crime in Fragile States. New York: International Peace Institute. 
The Global Initiative. 2011. The Global Initiative Against Transnational Organized Crime.

Transparency International. 2015. Tackle Instability and Terrorism by Fighting Corruption, February 4. https://www.transparency.org/news/feature/tackle_ instability_and_terrorism_by_fighting_corruption. Accessed 13 Nov 2017.

UN. 2010. Statement by the President of the Security Council. S/PRST/2010/4. New York: United Nations.

UN. 2013. Report of the Secretary-General on the Situation in Mali. S/2013/582. New York: United Nations.

UN. 2014a. Security Council Resolution 2185. New York: United Nations.

UN. 2014b. Security Council Resolution 2195. New York: United Nations.

UN. 2015a. Report of the Secretary-General on the Situation in Mali. S/2015/1030. New York: United Nations.

UN. 2015b. Security Council Resolution 2227. New York: United Nations.

UN. 2015c. Report of the Secretary-General on the Threat of Terrorists Benefiting from Transnational Organized Crime. S/2015/366. New York: United Nations.

UN. 2015d. Report of the Secretary-General on the Future of United Nations Peace Operations: Implementation of the Recommendations of the High-Level Independent Panel on Peace Operations. New York: United Nations.

UN. 2015e. Report of the High-level Independent Panel on Peace Operations on Uniting our Strengths for Peace: Politics, Partnership and People. New York: United Nations.

UN. 2016. Security Council Resolution 2295. New York: United Nations. UN. 2017. Security Council Resolution 2374. New York: United Nations.

UN Police. 2014. DPKO/DFS Policy on United Nations Police in Peacekeeping Operations and Special Political Missions. New York: United Nations.

UNODC. 2010. The Globalization of Crime - A Transnational Organized Crime Threat Assessment. Vienna: United Nations Office on Drugs and Crime. 
Open Access This chapter is licensed under the terms of the Creative Commons Attribution 4.0 International License (http://creativecommons.org/licenses/ by $/ 4.0 /$ ), which permits use, sharing, adaptation, distribution and reproduction in any medium or format, as long as you give appropriate credit to the original author(s) and the source, provide a link to the Creative Commons license and indicate if changes were made.

The images or other third party material in this chapter are included in the chapter's Creative Commons license, unless indicated otherwise in a credit line to the material. If material is not included in the chapter's Creative Commons license and your intended use is not permitted by statutory regulation or exceeds the permitted use, you will need to obtain permission directly from the copyright holder.

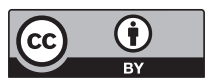

